opening this cyst, the walls of which were about two or three lines in thickness, a yellowish, foetid fluid escaped. The child, a male infant, fully formed, was now extracted without any difficulty; several parts of its body, the umbilical chord, and membranes, were in a state of putridity. The internal surface of the cyst was now seen, smooth in appearance, resembling serous membrane, and the placenta was iound attached to the verlebrse, between the arch of the stomach and the umbilicus. Being firmly fixed, no effort was made to remove the placenta, but the wound was immediately closed with sutures and adbesive plaster. All pain had disappeared; an abundant secretion of healthy pus was establish. ed, and on the 16th day after the operation the wound seemed to have closed al together. Madame S. now experienced an attack of pain something similar to labour-pains; in a few days the inferior portion of the incision opened, and from time to time a foctid sanies, containing membranous concretions, was discharged. At length, in the spring of 1827 , the wound was perfectly cicatrised, and Madame S. recovered her bealth and strength in the most perfect manner." Heidelberger Klinische Ann. B.6. H. 1.

ON THE

\section{TREATMENT OF GOUT,}

AND THE EFFECTS PRODUCED ON THE CONSTITUTION BY CERTAIN MEDICINES EM PLOYED IN ITS CURE.

By Patrick StarkeY, M.D.A.M.T.C.D., Licentiate of the King and Queen's College of Physicians in Ireland, Senior Physician to the Cork General Dispensary and Humane Society, \&c. \&c.

I IIATE read a garbled paragraph in the London Courier of the third of this month, purporting to be extracts from a lecture on the subject of gout, delivered by Sir Henry Halford before the College of Jhysicians of London at their last meeting, and a somewhat different version of the same iu the Literary Gazette, which I consider the more dangerous as coming under the sanction of so justly high a name as that of Sir Henry Halford; and as I am unwilling to charge that illustrious medical philosopher with either wilful error or in. consistency, I must conclude that he has been misquoted by lis reporters, the eirors and inconsistencies being theirs and not his.

In order to caution the public not to repose confidence in the doctrines contained in these documents, I feel it a duty I owe to the community to lay before them a few observations regarding the alleged contents of Sir Henry's prelection.

In the statements which I have to make, I shall confine myself to facts taken from long and woful experience in my. own person, having been afflicted with gout for upwards of twenty five years, during which time having received but very little benefit from the ordinary plans of treatment, $I$ was obliged to bave recourse to those fachionable poisons which had been introduced into practice from time to time, with the exception of eau medicinale, from which I was deterred by perusing Dr. Clutterbuck's excellent work on Gout; and being influenced by the high recommendation of colchicum, I used it, amongst the rest, in all its forms, with very bad results. I must however acknowledge with Sir Henry, that the acuteness of the continually-returning paroxysms was mitigated by its use, but they were frequent, with less vigour to bear them, and I had no other resource than to return to the use of that acrid poison; my general health was undermined, and my constitution, naturally very good, was gradually sinking, which all those who knew me observed and could testify, until it was reduced to the last $\mathrm{ebb} ; \mathrm{my}$ appetite was totally destroyed; (as what stomach could withstand the continual periodical ingurgitation of poison?) I had not felt the pleasurable sensation of hunger for fifteen years, and my mind was affected with the utmost despondency. I have thought it necessary to premise these observations before $I$ come to the minute consideration of Sir Henry's lecture.

He is reported to have said, that " there is no malady for which he prescribes with more confidence in the resources of our art than in gout; and that amongst the various remedies he cbiefly relies upon colchicum." We shull see how he bears himself out in this confidence, for he is not reported to have uttered a word respecting the prophylactic efficacy of that, or indeed of any other medicine, in removing the gouty diathesis from the constitution; but he says that, when gout manifests itself in the extremities, he does not commence its use immediately, but postpones the antidote till the disease shall have become fixed-that is, he lets the enemy into the citadel, that he may have the satisfaction of dislodging him. But he must often find him too stubborn in maintaining his position. Again, he admits that "occasionally some light preparation of bark is to be used in some worn-out frames, to reinvigorate them after the use of colchicum," although he asserts elsewhere " that it produces no untoward effects." This, to say the least of it, appears very contradictory and incon- 
sistent. To the charge of its good effects being only temporary, he answers thus :"Even so, whether three or four attacks, of as many days' duration each, were to be compared in the extent of suffering they produced, with the weight of six weeks' confinement, spring and autumn, which used to be the case before the virtues of colchicum were known; in addition to which, the evils resulting from the formation of chalk-stones in the joints, which are now almost totally done away by the control exercised by the medicine over the inflammatory stage of the disease." By this we see that he does not expect any curative effect from his favourite colchicum.

Again, he says that experience is against the correctness of the opinion that gout returns more frequently under the use of colchicum ; on the contrnry, he asserts " that when the vinous infusion is followed by the acetic extract, he holds himself justified in asserting that the attacks are removed to as long intervals as they used to be when left entirely to patience and Hannel!!" And this equalization of intervals is the only comfort held out to the unhappy patient to the end of his life, from the use of this drug! $\mathrm{by}$ the way, 1 beg leave to assert that more cripples have been made by the relaxing effects of the flannel system, and the debilitating and otherwise destructive use of the poisonous colchicum, than by gout itseif when left to nature's management alone. Finally, be says " that he far more depends upon the patient's mauagement of himself than on any medicines in keeping the malady at bay !!" Thus, then, his vaunted confidence depends more upon the patient's management than upon the efficacy of any medicine whatsoever.

As the columns of a newspaper, or even a miscellaneous periodical, are not suited to lengthened details, I shall conclude, for the present, with submitting a brief parallel between Sir Henry's confident practice, and that which has restored myself to perfect henlth, for which I am in a great measure indebted to accident, the parent of many of the mightiest advantages which man enjoys; Newton deduced the sublime doctrine of gravitation from the accidental fall of an apple!

Sir Henry prescribes with confidence.So do I, but with far different results I must think. He waits until the disease is fixedI strangle the paroxy $\mathrm{sm}$ in its commencement, and then take measures to remove the gouty predisposition, thus saving the constitution from suffering a loss of any portion of its vigour; he uses a poison-I use innoxious medicines; he offers no pro. pbylactic medicine-I do; be reduces the intervals in frequency to those of patience and flannel-I prolong them gradually; be mitigates the paroxysms-I extinguish them altogether; he leaves the constitution in a shattered state-I renovate it, and, finally, secure it against any return of the disease, unless the patient err. I trust then that $I$ may be allowed to assert, without the impu. tation of presumption, that $I$ have rescued the treatment of gout from the impositions of empirical hazard, and established it on the immutable basis of medical science, and that the prophylactic shall supersede henceforth the merely palliative course of treat. ment.

But I must acknowledge, in justice to the high character of Sir Henry, that he might fairly expect that the particulars of my system should be laid before him ere I exer. cised so rigorous a censorship over the con. tents of his lecture, especially as I had seen only fragments taken from it. 'lo this I can at present only reply, that the opinions of every public man become the property of the public, and, as such, are liable to be freely discussed, either wholly or in part, especially when they involve so weiglity a portion of the interests of the community, and that such discussion is not to be considered as directed to the man personally, but to his principles; and, secondly, that for the present my lips are sealed by the intervention of circumstances to which I must yield, but that, in a short time, I shall be disembarrassed of these circum. stances, and that a communication shall be made, which will satisfactorily acquit me with him and with the public.

Sir Henry thinks that colchicum is the bermodactyle of the ancients; but this is not very probable, for their characters are different; the latter being esteemed a mild aperient, whereas we know colchicum to bo a drastic, poisonous cathartic. 'The colchicum belongs to the class hexandria trigy. nia; and the hermodactyle to the triandria monogynia. Blancardus thinks it belongs to the aristolochia gynandria hexandria. His words are these:- " Hermodactylum dicunt esse colchici speciem quod vix credibile est, cum omnes t.jusmodı bulbi ad in. terius usque corculum tunicas habent qux in hermodactylis non reperiuntur; solidio$r \in m$ esse radicem crediderim, uti est aristo" lochia rotunda qua etiam tota in farinam facile tunditur, uti et hermodactyli ; figuram repræsentat corculi, in his alba est, ad fertur ad nos ex Syria-saporem habet in. sipidum et leniter purgat." -Vid. Blancard. ad Hermodactylum.

June, 1831. 